\title{
Investigation of multilayered packages resistance to free fall on the solid surface
}

\author{
L. Gegeckienè*, E. Kibirkštis**, V. Miliūnas***, V. Volkovas**** \\ *Kaunas University of Technology, Studentu 56, 51424 Kaunas, Lithuania, E-mail: laurosius@gmail.com \\ **Kaunas University of Technology, Studentu 56, 51424 Kaunas, Lithuania, E-mail: edmundas.kibirkstis@ktu.lt \\ ***Kaunas University of Technology, Studentu 56, 51424 Kaunas, Lithuania, E-mail: valdas.miliunas@ktu.lt \\ ****Technological System Diagnostic Institute, Kaunas University of Technology Kęstučio 27, 44312 Kaunas, Lithuania, \\ E-mail: vitalijus.volkovas@ktu.lt
}

crossref http://dx.doi.org/10.5755/j01.mech.17.2.328

\section{Introduction}

Since the package is designed to store, protect, manage, distribute and represent the product, but its most important purpose - to protect, that the product would not be damaged or (and) lost. In order to reduce the quantity of materials and waste, the entire system must be optimized the part of which is the package [1,2].

In many cases packaging became the necessary element of production and in their realization process. At present many products are packed in flexible and rigid plastic packaging, which may well protect the product against the environmental impact and is relatively light, durable and cheap, but the use of the paper and cardboard in packaging as cheap and "green" material is still unabated [1-4]. A number of papers analyzing the dynamics of these packages have been published. The aim of paper [5] was to carry out tests in order to determine the effect of the graphical paperboard package bottom construction and bottom dimensions on the package resistance to fall shock loads. The obtained investigation results show that for the package edge deformations, when a package is dropped onto the bottom plane, the drop height has no effect. When a package falls onto the long edge, the edge deformation increases with the increasing drop height. Height had the greatest impact on the package when the package fell onto the short bottom edge when $67 \%$ of tested packages bottom broke.

Strength and fracture parameters are very important, because during exploitation damage gradually appears in the constructions materials and results their fracture. So, in recent years, there have been a lot of requirements for ecological and performance criteria of packages. In addition not only the static but also and dynamics loads, when the package during the transportation could fall or could effected by vibrations [6-8].

Other authors [9-15] studied the effect of the shape of the protective packaging materials inside a corrugated paperboard box on the loads caused by falling shocks and caused by others dynamics loads. During the tests it was observed how many goods were damaged or the deformations or cracks were measured, or visual assessment was performed according to relevant criteria.

High-quality products are competitive only if it is properly packaged. That's why the matter under investigation are importance and topical.

So the aim of this present study is to estimate the characteristics of deformation and behaviour of multilayered packages free fall on the solid surface.

\section{Experiment equipment and method}

The combined package, used for packaging of food products, usually consists of paperboard, coated with the layers of polyethylene (Fig. 1). The inner polyethylene layer serves as a container for liquids products, also this layer allows to weld on and to seal the package by filling with the liquid product. The outer polyethylene layer is thinner, and its purpose is to prevent the penetration of moisture and bacteria into the paperboard. Also it is used as the layer for welding for the final formation of package. If the packed product is used for long-term storing, between the inner polyethyelene layer and paperboard, the layer of aluminium is placed. This layer is a reliable barrier to bacteria and other impurities, but also prevents from the light penetration. Then the product is packed in such bacteria impermeable sterile package under aseptic conditions in the absence of microorganisms inside the package and there is no possibility for them to penetrate from the outside, the packed products can be stored and transported in a long time without refrigeration [3-4].

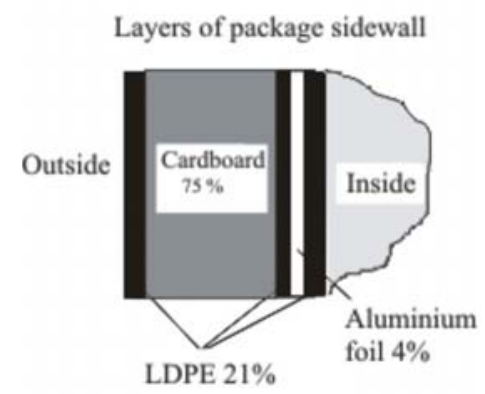

Fig. 1 The sidewall structure of package, made from composite materials. $\mathrm{PE}$ - polyethylene, $\mathrm{Al}$ - aluminium layer

The volume of packages used for the tests was 0.5 1, 11 and 21 . These types of packages are widely used for various beverage packaging.

The tests of multilayered packages were carried out at the temperature $20 \pm 2{ }^{\circ} \mathrm{C}$ and air humidity $65 \pm 2 \%$.

For the tests of the package resistance to free fall on the solid surface the special stand was used, which outer view is presented in Fig. 2, a and the simplified scheme in Fig. 2, b. The sequence of the tests is presented in Fig. 3.

During the test, the multilayered package was fixed with the thread in a special stand, and then it fell on supporting plate 2 , in which the sensor 7 was build-in. The force impulse, which was measured by the measurement equipment, presented in Fig. 2, a, was showed on the 
screen of personal computer. Impulse was calculated according to the general formulas

$$
S=\int_{0}^{t} F(t) d t
$$

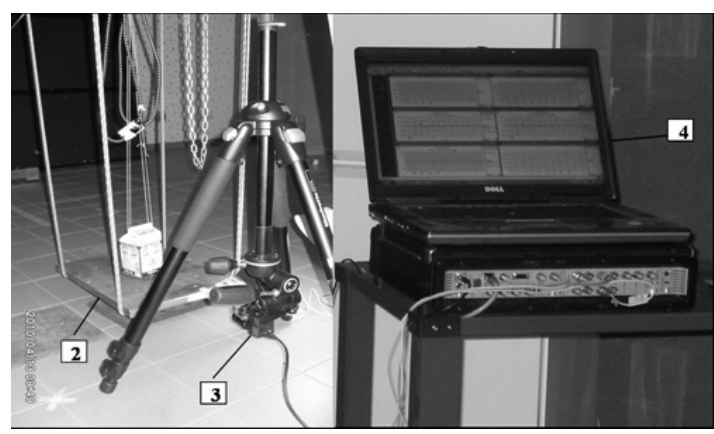

a

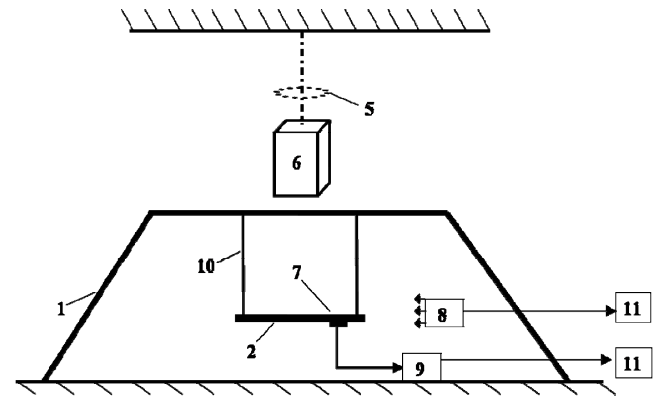

$\mathrm{b}$

Fig. 2 The tests stand and their simplified scheme: a) the outer view of stand: 1 -rigid stand, 2 -suspended supporting plate with the built-in seismic sensor, 3-high-speed camera, 4-personal computer; b) simplified scheme of the stand: 1 -stand, $5-$ detachment mechanism, 6-sample, 7-sensor, 8 - high - speed camera, 9 - converter, 10 - flexible tread, $11-$ personal computer

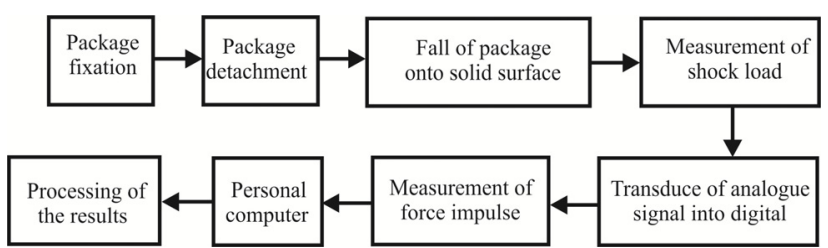

Fig. 3 The block scheme of the sequence of the test of package resistance to shock impact

The deformation process of the package was captured by high - speed camera 8 , and the effect of shock load to the package was recorded by the measurement equipment.

\section{Results and discussion}

The graphs of shock load variation when the multilayered package falls from 1 and $0.5 \mathrm{~m}$ height are presented in Fig. 4. The images of package deformation process recorded in a high-speed video camera are presented in Fig. 5.

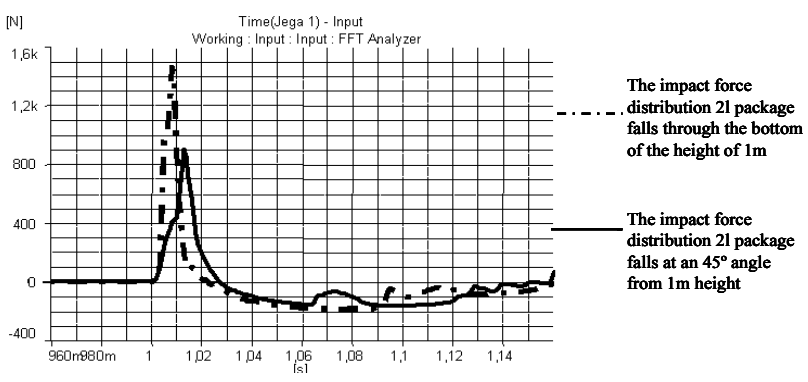

a

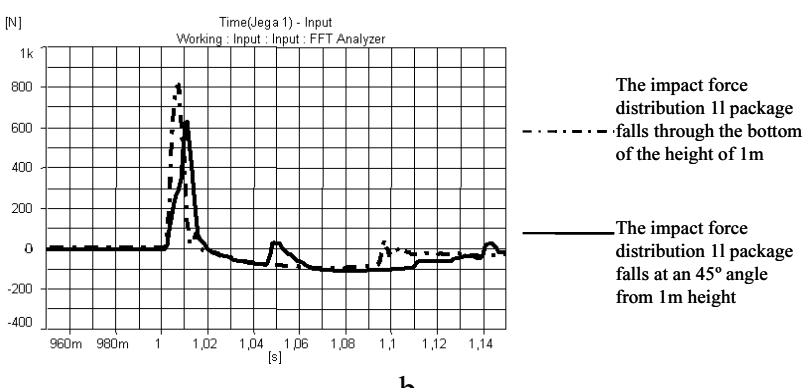

$\mathrm{b}$

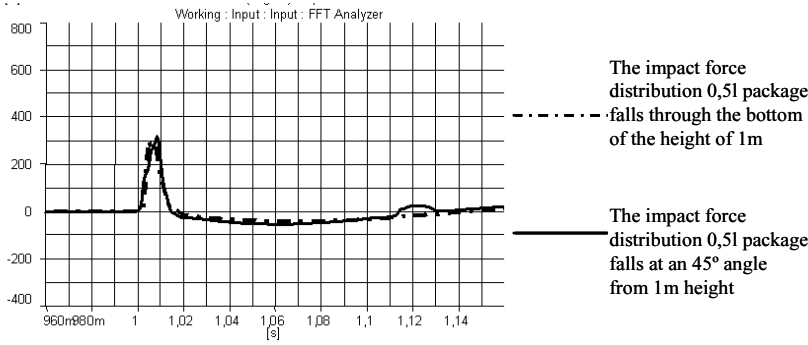

c

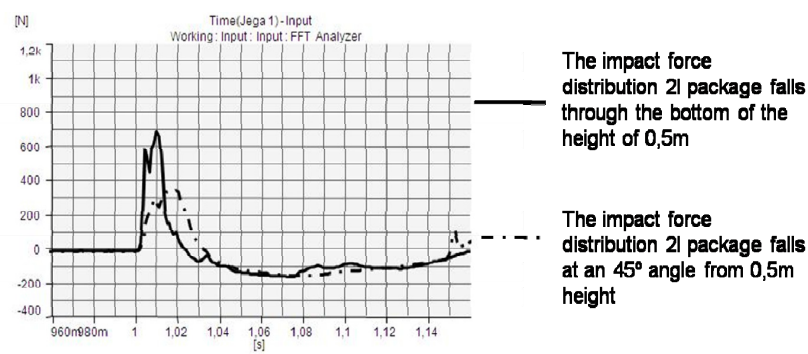

d

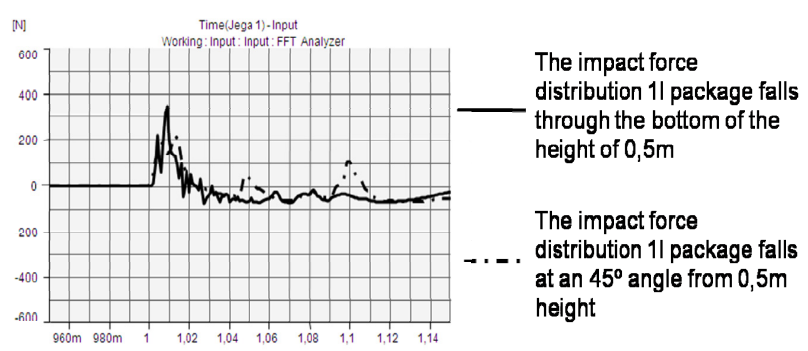

e

Fig. 4 Variation of shock load of multilayered packages, when it fall from 1 and 0.5 height: a) shock load of 21 package, when it falls on bottom from $1 \mathrm{~m}$ height; b) shock load of 11 package, when it falls on bottom from $1 \mathrm{~m}$ height $\mathrm{c}$ ) shock load of 0.51 package, when it falls on bottom from $1 \mathrm{~m}$ height; d) shock load of 21 package, when it falls on bottom from $0.5 \mathrm{~m}$ height; e) shock load of 11 package, when it falls on bottom from 0.5 height

Table 1 presents the results of the tests. 
Table 1

The tests results of multilayered packages resistance to free fall on the solid surface

\begin{tabular}{|c|c|c|c|c|c|c|c|c|c|}
\hline $\begin{array}{c}\text { Package } \\
\text { code* }\end{array}$ & $\begin{array}{c}\text { Package } \\
\text { volume } \\
1\end{array}$ & $\begin{array}{l}\text { Package } \\
\text { mass, kg }\end{array}$ & $\begin{array}{c}\text { Package } \\
\text { height } H, \\
\times 10^{-2} \mathrm{~m}\end{array}$ & $\begin{array}{c}\text { Package } \\
\text { bottom width } \\
B, \times 10^{-2} \mathrm{~m}\end{array}$ & $\begin{array}{c}\text { Package bottom } \\
\text { length, } L, \times 10^{-2} \\
\mathrm{~m}\end{array}$ & $\begin{array}{l}\text { Averaged length of } \\
\text { deformed package } \\
\text { edges, } \times 10^{-2} \mathrm{~m}\end{array}$ & \begin{tabular}{|} 
Force impulse, \\
$\mathrm{N}$
\end{tabular} & \begin{tabular}{c|} 
Drop \\
height, $\mathrm{m}$
\end{tabular} & $\begin{array}{c}\text { Orientation of } \\
\text { package static state } \\
\text { before drop }\end{array}$ \\
\hline 1.d.1 & 2 & 2.094 & 2.65 & 0.9 & 0.9 & 0.392 & 1260 & \multirow{18}{*}{1} & \multirow{3}{*}{$\begin{array}{c}\text { Package bottom } \\
\text { plane is horizon- } \\
\text { tal }\end{array}$} \\
\hline 2.d.1 & 2 & 2.094 & 2.65 & 0.9 & 0.9 & 0.389 & 1450 & & \\
\hline 3.d.1 & 2 & 2.094 & 2.65 & 0.9 & 0.9 & 0.438 & 1320 & & \\
\hline $1 . \mathrm{k} .1$ & 2 & 2.094 & 2.65 & 0.9 & 0.9 & 0.63 & 873 & & \multirow{3}{*}{$\begin{array}{c}\text { Package bottom } \\
\text { edge is inclined } \\
\text { by } 45^{\circ}\end{array}$} \\
\hline 2.k.1 & 2 & 2.094 & 2.65 & 0.9 & 0.9 & 0.604 & 899 & & \\
\hline $3 . \mathrm{k} .1$ & 2 & 2.094 & 2.65 & 0.9 & 0.9 & 0.645 & 883 & & \\
\hline 1.d.1 & 1 & 1.047 & 1.925 & 0.7 & 0.7 & 0.004 & 808 & & \multirow{3}{*}{$\begin{array}{c}\text { Package bottom } \\
\text { plane is horizon- } \\
\text { tal }\end{array}$} \\
\hline 2.d.1 & 1 & 1.047 & 1.925 & 0.7 & 0.7 & 0.018 & 815 & & \\
\hline 3.d.1 & 1 & 1.047 & 1.925 & 0.7 & 0.7 & 0.009 & 835 & & \\
\hline $1 . \mathrm{k} .1$ & 1 & 1.047 & 1.925 & 0.7 & 0.7 & 0.05 & 543 & & \multirow{3}{*}{$\begin{array}{l}\text { Package bottom } \\
\text { edge is inclined } \\
\text { by } 45^{\circ}\end{array}$} \\
\hline 2.k.1 & 1 & 1.047 & 1.925 & 0.7 & 0.7 & 0.067 & 655 & & \\
\hline $3 . \mathrm{k} .1$ & 1 & 1.047 & 1.925 & 0.7 & 0.7 & 0.059 & 635 & & \\
\hline 1.d.1 & 0.5 & 0.524 & 0.94 & 0.7 & 0.7 & 0.002 & 294 & & \multirow{3}{*}{$\begin{array}{l}\text { Package bottom } \\
\text { plane is horizon- } \\
\text { tal }\end{array}$} \\
\hline 2.d.1 & 0.5 & 0.524 & 0.94 & 0.7 & 0.7 & 0.001 & 283 & & \\
\hline 3.d.1 & 0.5 & 0.524 & 0.94 & 0.7 & 0.7 & 0.002 & 289 & & \\
\hline 1.k.1 & 0.5 & 0.524 & 0.94 & 0.7 & 0.7 & 0.147 & 339 & & \multirow{3}{*}{$\begin{array}{c}\text { Package bottom } \\
\text { edge is inclined } \\
\text { by } 45^{\circ}\end{array}$} \\
\hline 2.k.1 & 0.5 & 0.524 & 0.94 & 0.7 & 0.7 & 0.132 & 397 & & \\
\hline 3.k.1 & 0.5 & 0.524 & 0.94 & 0.7 & 0.7 & 0.151 & 386 & & \\
\hline 1.d.0 & 2 & 2.094 & 2.65 & 0.9 & 0.9 & 0.492 & 685 & \multirow{18}{*}{0.5} & \multirow{3}{*}{$\begin{array}{l}\text { Package bottom } \\
\text { plane is horizon- } \\
\text { tal }\end{array}$} \\
\hline 2.d.0 & 2 & 2.094 & 2.65 & 0.9 & 0.9 & 0.494 & 791 & & \\
\hline 3.d.0 & 2 & 2.094 & 2.65 & 0.9 & 0.9 & 0.488 & 660 & & \\
\hline 1.k.0 & 2 & 2.094 & 2.65 & 0.9 & 0.9 & 0.57 & 344 & & \multirow{3}{*}{$\begin{array}{c}\text { Package bottom } \\
\text { edge is inclined } \\
\text { by } 45^{\circ}\end{array}$} \\
\hline 2.k.0 & 2 & 2.094 & 2.65 & 0.9 & 0.9 & 0.548 & 401 & & \\
\hline 3.k.0 & 2 & 2.094 & 2.65 & 0.9 & 0.9 & 0.541 & 400 & & \\
\hline 1.d.0 & 1 & 1.047 & 1.925 & 0.7 & 0.7 & 0.002 & 492 & & \multirow{3}{*}{$\begin{array}{c}\text { Package bottom } \\
\text { plane is horizon- } \\
\text { tal }\end{array}$} \\
\hline 2.d.0 & 1 & 1.047 & 1.925 & 0.7 & 0.7 & 0.001 & 501 & & \\
\hline 3.d.0 & 1 & 1.047 & 1.925 & 0.7 & 0.7 & 0.004 & 505 & & \\
\hline 1.k.0 & 1 & 1.047 & 1.925 & 0.7 & 0.7 & 0.017 & 214 & & \multirow{3}{*}{$\begin{array}{l}\text { Package bottom } \\
\text { edge is inclined } \\
\text { by } 45^{\circ}\end{array}$} \\
\hline 2.k.0 & 1 & 1.047 & 1.925 & 0.7 & 0.7 & 0.024 & 271 & & \\
\hline 3.k.0 & 1 & 1.047 & 1.925 & 0.7 & 0.7 & 0.035 & 293 & & \\
\hline 1.d.0 & 0.5 & 0.524 & 0.94 & 0.7 & 0.7 & 0.001 & 200 & & \multirow{3}{*}{$\begin{array}{c}\text { Package bottom } \\
\text { plane is horizon- } \\
\text { tal }\end{array}$} \\
\hline 2.d.0 & 0.5 & 0.524 & 0.94 & 0.7 & 0.7 & 0.001 & 255 & & \\
\hline 3.d.0 & 0.5 & 0.524 & 0.94 & 0.7 & 0.7 & 0.001 & 267 & & \\
\hline 1.k.0 & 0.5 & 0.524 & 0.94 & 0.7 & 0.7 & 0.069 & 209 & & \multirow{3}{*}{$\begin{array}{c}\text { Package bottom } \\
\text { edge is inclined } \\
\text { by } 45^{\circ}\end{array}$} \\
\hline 2.k.0 & 0.5 & 0.524 & 0.94 & 0.7 & 0.7 & 0.078 & 197 & & \\
\hline 3.k.0 & 0.5 & 0.524 & 0.94 & 0.7 & 0.7 & 0.078 & 219 & & \\
\hline
\end{tabular}

*-1.d.1 -1- number of sample; d - state of fall; 1- drop height.
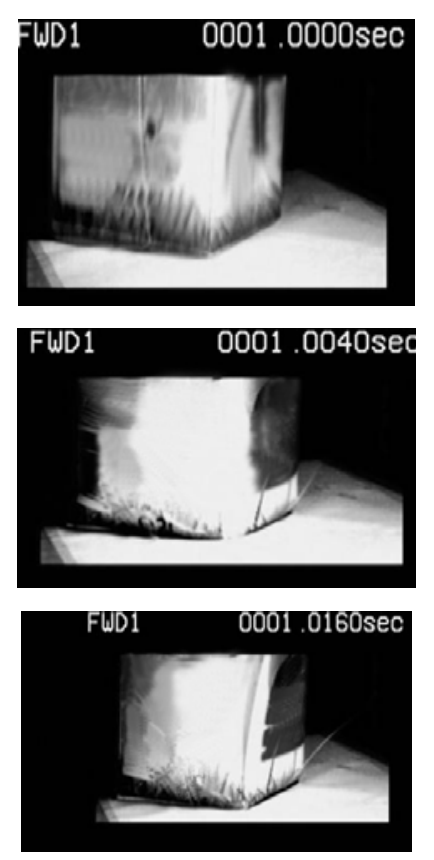

a
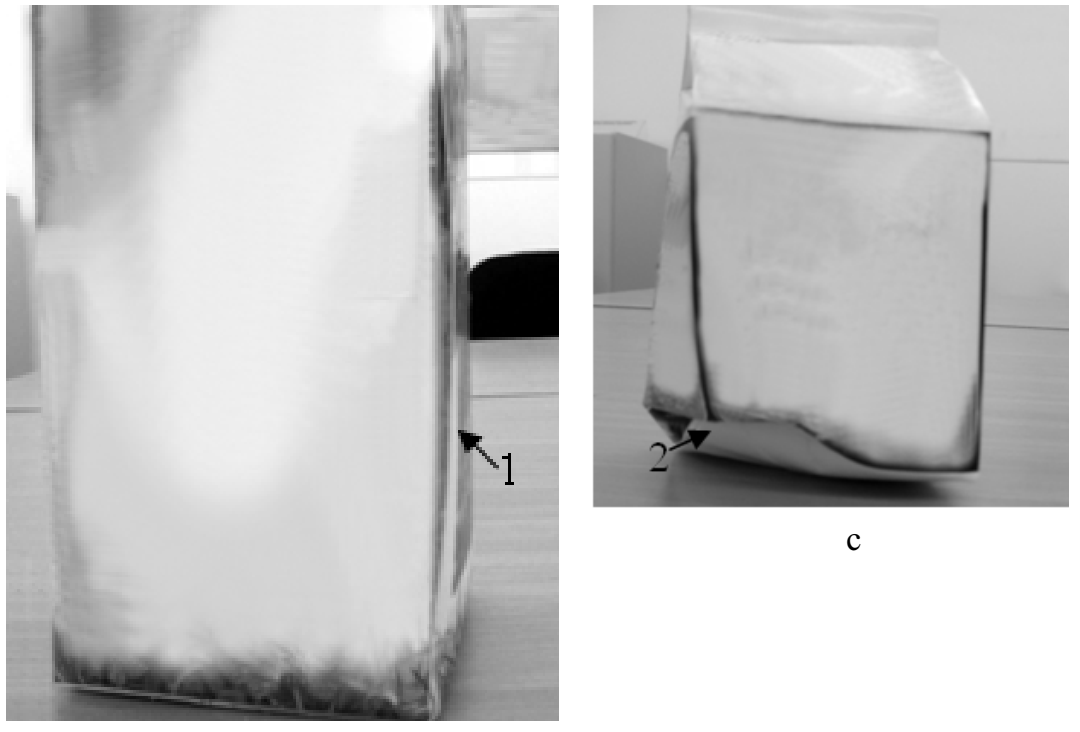

C

b

Fig. 5 External view of packages deformations: a) 21 package deformation process recorded in a high-speed video camera b) 21 package, which was fallen on the bottom, 1 - crack through the adhesive joint; c) 0.51 package, which was fallen on the edge inclined by $45^{\circ}, 2$ - deformation of package edge 
From the first graph in Fig. 4 it can be seen, that, the shock load, when the 21 package falls onto the bottom from $1 \mathrm{~m} \sim 1.4 \mathrm{kN}$, and when the bottom edge is inclined by $45^{\circ} \sim 900 \mathrm{~N}$. When 11 package falls from $1 \mathrm{~m}$ height on the bottom, it cracks through the adhesive joint (Fig. 5, a). The averaged length of four deformed package edges $\approx 0.406 \times 10^{-2} \mathrm{~m}$. When the 21 package falls from 1 $\mathrm{m}$ height on the edge, inclined by $45^{\circ}$, the averaged length of deformed edge is $\approx 0.626 \times 10^{-2} \mathrm{~m}$.

The shock load, when 11 package falls on the bottom from $1 \mathrm{~m}$ height $\sim 808 \mathrm{~N}$, and when the bottom edge is inclined by $45^{\circ} \sim 610 \mathrm{~N}$. The averaged length of four deformed package edges $\approx 0.01 \times 10^{-2} \mathrm{~m}$, so from the obtained results it can be argued, that the fall from $1 \mathrm{~m}$ height to such volume package doesn't affect the resistance to shock loads because the deformations of edges are even smaller as mentioned above. When the package falls on the edge, inclined by $45^{\circ}$, no essential deformations were determined.

The shock load, when 0.51 package falls on the bottom from $1 \mathrm{~m}$ height $\sim 295 \mathrm{~N}$, and when the bottom edge is inclined by $45^{\circ} \sim 340 \mathrm{~N}$. The averaged length of four deformed package edges $\approx 0.002 \times 10^{-2} \mathrm{~m}$, so from the obtained results it can be seen that the drop from $1 \mathrm{~m}$ height of 0.51 package on the bottom doesn't have influence. When the 0.51 package falls from $1 \mathrm{~m}$ height on the edge, inclined by $45^{\circ}$, the averaged length of deformed edge is $\approx 0.055 \times 10^{-2} \mathrm{~m}$. It can be argued (Fig. 5, b), that the fall from $1 \mathrm{~m}$ height on the edge is dangerous for the 0.51 package, because the deformations are quite large.

The averaged length of four deformed package edges, when the 21 package falls from $0.5 \mathrm{~m}$ height on the bottom is $\approx 0.491 \times 10^{-2} \mathrm{~m}$. These results show, that the averaged length of four deformed package edges don't differ significantly from the averaged length, when 21 package falls from $1 \mathrm{~m}$ height, but in this case, the package doesn't cracks through adhesive joints. When the 21 package falls from $0.5 \mathrm{~m}$ height on the edge, inclined by $45^{\circ}$, the averaged length of deformed edge is $\approx 0.553 \times 10^{-2} \mathrm{~m}$. So it can be argued, that the fall from 0.5 and from $1 \mathrm{~m}$ height on the edge, inclined by $45^{\circ}$ for 21 package is not so dangerous, because the deformations aren't so large.

When the 11 package falls from $0.5 \mathrm{~m}$ height on the bottom, the averaged length of four deformed package edges $\approx 0.002 \times 10^{-2} \mathrm{~m}$, so the obtained results show that the fall of 11 package from 0.5 (analogical as from $1 \mathrm{~m}$ ) height doesn't have significant influence. When the 11 package falls from $0.5 \mathrm{~m}$ height on the edge, inclined by $45^{\circ}$, the averaged length of deformed edge is $\approx 0.025 \times 10^{-2}$ $\mathrm{m}$, so in this case the deformed edge of 11 package is quite resistant for such shock.

It was determined, that, the averaged length of four deformed package edges is $\approx 0.001 \times 10^{-2} \mathrm{~m}$, when the 0.51 package falls from $0.5 \mathrm{~m}$ height on the bottom. So this case of the fall also doesn't influence the resistance of this volume package. When the 0.51 package falls from $0.5 \mathrm{~m}$ height on the edge, inclined by $45^{\circ}$, the averaged length of deformed edge is $\approx 0.075 \times 10^{-2} \mathrm{~m}$. The obtained results show, that the fall of 0.51 package from 0.5 height on the edge, inclined by $45^{\circ}$ is also dangerous as the fall from $1 \mathrm{~m}$ height.

\section{Conclusions}

1. It was obtained, that the drop from $1 \mathrm{~m}$ and 0.5 $\mathrm{m}$ height on solid surface of 11 and 0.51 packages doesn' $t$ have an influence. The packages deform slightly, so this height are not dangerous for them.

2. The deformations of 0.51 package are quite large, when the package falls from $0.5 \mathrm{~m}$ and $1 \mathrm{~m}$ height on the edge inclined by $45^{\circ}$. Such package becomes no longer suitable for further usage.

3. The experiment results showed, that deformations of multilayered packages highly depend on what angle and from what height it fall.

4. It can be argued, that the fall of 21 package on the bottom is more dangerous than the fall on the edge. In comparison: the shock load then package falls from $1 \mathrm{~m}$ height on the bottom $\sim 808 \mathrm{~N}$, and on the edge inclined by $45^{\circ} \sim 610 \mathrm{~N}$.

5. The comparison between different size packages from different height under the same conditions, it was obtained, that the force impulse is smaller, when the package falls on the edge, but it causes larger deformations.

6. The analysis of results showed, that the increase of package volume, the more difficult it can withstand the shock load, it cracks through the adhesive joint.

7. The obtained testing results can be applied in the process of packages designing.

\section{References}

1. Danys, J.; Lebedys, A. 2004. Foods Packaging development trends in Europe, Food chemistry and technology 38(1). Kaunas: 15-26 (in Lithuanian).

2. Directive 2004/12/EC of the European Parliament and of the Council of 11 February 2004 amending Directive 94/62/EC on packaging and packaging waste// Official Journal of the European Union. No. L 47, 18/02/2004.

3. Flanderka, F.; Herodin, B. Effective packaging effective prevention“. http://www.proeuropecongress.com/pdf/prevention.pdf.

4. Thorén A.; Vinberg B. 2000. Pocket Book of Packaging. Packforsk, Kista. 120p.

5. Bivainis, V.; Kibirkštis, E.; Lebedys, A. 2010, Experimental studies on drop test of filled coated graphical board packages. Mechanika 2010: proceedings of the 15th international conference, April 8-9, 2010, Kaunas, Lithuania: 75-79.

6. Žiliukas, A.; Surantas, A.; Žiogas, G. 2010. Strength and fracture criteria application in stress concentrators areas, Mechnika 3(83): 17-20.

7. Daunys, M.; Česnavičius, R. 2009. Low cycle stress structures and fatigue under tension-compression and torsion, Mechnika 6(80): 5-11.

8. Miliūnas, V.; Kibirkštis, E.; Dagytė, I.; Bivainis, V.; Kulaitytė, V. 2010. Investigation of packages and their structure elements. Mechanika 2010: proceedings of the 15th international conference, April 8-9, 2010, Kaunas, Lithuania: 320-324.

9. Sharan, G.; Srivastav, S.; Rawale, K. P.; Dave, U. 2009. Development of corrugated fibre board cartons for long distance transport of tomatoes in India, International Journal for Service Learning in Engineering. Penn State University, vol. 4, no 1: 31-43. 
10. Prabakaran, B. Naganathan, Jorge, A. 1995. Marcondes. Effect of specimen size on test results to determine cushioning characteristics of corrugated fibreboard, Packaging Technology and Science 8(2): 85-95.

11. Volkovas, V.; Slavickas, E.S.; Mačiulis, D. 2007. Shock and vibration testing of TV tare's box. Mechanika 2007: proceedings of the 12th international conference, April 5, 2007, Kaunas University of Technology, Lithuania: 280-284.

12. Mourad, A.; Garcia, E.; Gustavo, Braz V.; Von Zuben, F. 2008. Influence of recycling rate increase of aseptic carton for long-life milk on GWP reduction. Resources, Conservation and Recycling. 52: 678-689.

13. Kabelkaitė, A.; Miliūnas, V.; Gegeckienè, L.; Kibirkštis, E.; Ragulskis, L.; Volkovas, V. 2010. Investigation of packages resistance under dynamics loads, Journal of Vibroengineering 12(4): 566-572.

14. Sek, M.A. 1996. A modern technique of transportation simulation for package performance testing, Packaging Technology and Science 9: 327-343.

15. Garcia-Romeu-Martinez, M.A.; Sek, M.A.; Cloquell-Ballester, V.A. 2009. Effect of initial precompression of corrugated paperboard cushions on shock attenuation characteristics in repetitive impacts, Packaging Technology and Science 22: 323-334.

\section{Gegeckienė, E. Kibirkštis, V. Miliūnas,}

V. Volkovas

\section{DAUGIASLUOKSNIŲ PAKUOČIU ATSPARUMO KRITIMUI ANT KIETO PAVIRŠIAUS TYRIMAS}

\section{R e z i u m è}

Nagrinèta daugiasluoksnių pakuočių kritimo ant kieto paviršiaus deformacijos ir elgsenos ypatumai. Jejgos impulsų reikšmès nustatytos naudojant matavimo aparatūra, prie kurios prijungtas personalinis kompiuteris. Vizualuji pakuotès deformacijos procesą fiksavo greitaveikè filmavimo kamera. Šiais metodais apdoroti duomenys leido spręsti, koks aukštis ar kokia kritimo padètis pakuotei yra pavojingiausi. Tyrimo rezultatai taikomi tolesniame pakuočių projektavimo procese.
L. Gegeckienė, E. Kibirkštis, V. Miliūnas, V. Volkovas

\section{INVESTIGATION OF MULTILAYERED PACKAGES RESISTANCE TO FREE FALL ON THE SOLID SURFACE}

\section{S u m m a r y}

The characteristics of deformations and behaviour of multilayered packages fall on the solid surface were analyzed. The force impulses by using measuring equipment, which was connected to the PC were determined. The visual process of package deformation was captured by the high - speed camera. The obtained results allowed to decide, what height or what static state before fall is the most dangerous for the package. Test results are applied in the further process of packages designing.

Л. Гегецкиене, Е. Кибиркштис, В. Милюнас, В. Волковас

\section{ИССЛЕДОВАНИЕ СОПРОТИВЛЕНИЯ \\ МНОГОСЛОЙНЫХ УПАКОВОК ПРИ ПАДЕНИИ ИХ НА ЖЁСТКУЮ ПОВЕРХНОСТЬ}

P е 3 ю м е

Проведен анализ особенностей деформаций и поведение многослойных упаковок при их падении на твердую поверхность. Импульс силы измерен при использовании измерительной аппаратуры, подсоединенной к персональному компьютеру. Визуальный процесс деформаций упаковки фиксировала быстродействующая камера съемки.

Полученные данные исследований позволяют судить, какая высота и положение падения упаковки является наиболее опасной. Результаты исследований могут быть использованы в процессе проектирования упаковок.
Received November 25, 2010 Accepted April 15, 2011 